\title{
Comparative leaf anatomy of four species of Bromelioideae (Bromeliaceae) occurring in the Atlantic Forest, Brazil
}

\author{
Tiago Augusto Rodrigues Pereira, Tuane Santos de Oliveira, \\ Luzimar Campos da Silva, and Aristéa Alves Azevedo
}

\begin{abstract}
Bromeliaceae, comprising 3172 species, is one of the most important families of the Brazilian Atlantic Forest owing to its high degree of endemism and occurrence in different habitats. The subfamily Bromelioideae is the most representative of Bromeliaceae and the best represented in the state of Minas Gerais, Brazil, with 120 species. The objective of this study is to compare the leaf anatomy of four species found in two areas of the Atlantic Forest: Serra do Brigadeiro State Park, Minas Gerais, Brazil (Quesnelia strobilispica Wawra and Wittrockia gigantea (Baker) Leme) and a forest fragment located within Bom Sucesso Farm, Viçosa, Minas Gerais, Brazil (Billbergia euphemiae E. Morren and Bromelia antiacantha Bertol.), relating environmental characteristics to the habit. Leaf samples were studied using light and scanning electron microscopy and histochemical tests with Sudan, phloroglucinol, and ruthenium red stains. Leaves of B. euphemiae and W. gigantea showed several adaptations to the epiphytic habit, including scales on both surfaces, thickened epidermal cell walls, presence of silica bodies, hypodermis with sclerified cells, water-storing tissue (hydrenchyma), and air channels formed by stellate cells in the chlorenchyma. The epiphytic species B. euphemiae and the terrestrial species $Q$. strobilispica have similar overall structure, including a well-developed parenchyma and extravascular fiber groups. Leaves of the terrestrial species Bromelia antiacantha and the epiphytic species W. gigantea also show structural similarities, such as lack of extravascular fibers and less developed parenchyma. Similar characteristics in species from different habitats may either reflect microclimatic conditions under which these species occur or genetically fixed characteristics.
\end{abstract}

Key words: Billbergia euphemiae, Bromelia antiacantha, Quesnelia strobilispica, Wittrockia gigantea, epiphytism.

Résumé : Les Bromeliaceae, comprenant 3172 espèces, constituent une des familles les plus importantes de la forêt atlantique brésilienne par son fort degré d'endémisme et par sa présence dans différents habitats. La sous-famille des Bromelioideae, la plus représentative des Bromeliaceae, est la mieux représentée dans l'état de Minas Gerais, au Brésil, avec 120 espèces. L'objectif de l'étude consiste à comparer l'anatomie foliaire de quatre espèces trouvées dans deux régions de la forêt atlantique : parc de l'état «Serra do Brigadeiro », MG, Brésil (Quesnelia strobilispica Wawra et Wittrockia gigantea (Baker) Leme), et un fragment forestier localisé sur la ferme «Bom Sucesso », Viçosa, MG, Brésil (Billbergia euphemiae E. Morren et Bromelia antiacantha Bertol.), en reliant les caractéristiques environnementales avec l'habitat. Les auteurs ont étudié les feuilles à l'aide de la microscopie photonique et électronique par balayage, ainsi que des colorations au Sudan, phloroglucinol, et rouge de ruthénium. Les feuilles du B. euphemiae et du W. gigantea montrent plusieurs adaptations à l'habitat épiphyte, incluant des écailles sur les deux surfaces, des parois cellulaires épaissies, la présence de corps siliceux, un hypoderme avec des cellules sclérifiées, des tissus accumulateurs d'eau (hydranchymes) et des canaux aérifères formés par des cellules stellées, dans le chlorenchyme. L'espèce épiphyte, $B$. euphemiae, et l'espèce terrestre, $Q$. strobilispica, possèdent en général des structures similaires, incluant un parenchyme bien développé et des groupes de fibres extra-vasculaires. Les feuilles de l'espèce terrestre, $B$. antiacantha, et de l'espèce épiphyte, $W$. gigantea, montrent également des similarités de structures comme l'absence de fibres extra-vasculaires et un parenchyme moins développé. La similitude des caractères chez des espèces provenant de différents habitats peut refléter soit les conditions microclimatiques sous lesquelles ces espèces se développent, ou encore des caractéristiques génétiques fixées.

Mots-clés : Billbergia euphemiae, Bromelia antiacantha, Quesnelia strobilispica, Wittrockia gigantea, épiphytisme.

[Traduit par la Rédaction]

Received 14 September 2010. Accepted 1 February 2011.

Published at www.nrcresearchpress.com/cjb on 1 April 2011.

T.A.R. Pereira, T.S. de Oliveira, L.C. da Silva, and A.A. Azevedo. Universidade Federal de Viçosa, Departamento de Biologia Vegetal, Avenida Peter Henry Rolfs, s/n, Campus Universitário, CEP 36.570-000, Viçosa, Minas Gerais, Brazil.

Corresponding author: Luzimar Campos da Silva (e-mail: luzimar@ufv.br).

\section{Introduction}

The family Bromeliaceae currently comprises 58 genera and 3172 species (Luther 2008) widely distributed throughout the neotropics, except for Pitcairnia feliciana (A.Chev.) Harms \& Mildbr., the only species found in Africa (JacquesFelix 2000). Traditionally, the family comprises three subfamilies: Bromelioideae, Pitcairnioideae, and Tillandsioideae, which are separated according to their floral characteristics, habit, and morphology of fruits and seeds (Smith and Downs 
1974, 1977, 1979). Recent molecular studies have suggested increasing the number of subfamilies, maintaining the circumscription of the subfamilies Bromelioideae and Tillandsioideae, which are clearly monophyletic, but dividing the subfamily Pitcairnioideae, which proved highly paraphyletic, into five subfamilies: Brocchiniodeae, Hechtioideae, Lindmanioideae, Navioideae, and Puyoideae, as well as Pitcairnioideae itself (Givnish et al. 2007).

In the past, the Atlantic Forest covered approximately 1.2 million $\mathrm{km}^{2}$, corresponding to $15 \%$ of the Brazilian territory. It stretches along Brazil's Atlantic coast, from the northern state of Rio Grande do Norte to the southern state of Rio Grande do Sul. Today more than $85 \%$ of this forest has been cleared and what remains is highly fragmented. Estimates are that only $8 \%$, less than $100000 \mathrm{~km}^{2}$, are still intact (Fundação SOS Mata Atlântica and Instituto Nacional de Pesquisas Espaciais 2008).

Bromeliaceae is one of the families of greatest richness and diversity in the Atlantic Forest. The current record indicates 31 genera, 803 species, and 150 infraspecific taxa (Martinelli et al. 2008). In Minas Gerais, the family is represented by 27 genera, 265 species, and 18 infraspecific taxa distributed in different biomes. Ninety-eight species are endemic to Minas Gerais (37\% of the total), highlighting the richness of the Bromeliaceae flora in the state. Bromelioideae is the best represented of the three subfamilies, with 19 genera (70\% of the total) and 120 species. The region is recognized as a centre of diversification for this subfamily (Versieux and Wendt 2006, 2007).

Bromeliaceae are distributed in a wide variety of habitats. They can be terrestrial, saxicolous, epiphytic, or rupicolous, and are known for their ability to occupy arid and nutrient poor environments (Smith and Downs 1974; Reitz 1983; Benzing 2000). Adaptive strategies to cope with water deficits found in the family include the rosette phyllotaxy forming reservoir tanks; water storage tissues in roots, stems, or leaves; and the presence of scale-like trichomes, which are also used for water and nutrient absorption (Benzing 2000). Important leaf anatomical adaptations include epidermissclerified hypodermis complex, well-developed aquiferous hypodermis, and air channels arranged longitudinally and parallel to vascular bundles, in addition to the scales (Tomlinson 1969; Benzing 2000).

Leaf anatomical studies of Bromeliaceae species have proven to be extremely valuable for studies on phylogeny, physiology, ecology, and taxonomy because of the great diversity and structural variability in representatives of the family (Benzing 2000).

Tomlinson's (1969) work is one of the most important studies on the family. His work provides anatomical data on vegetative organs of representatives of the three subfamilies, with focus on taxonomic and ecological aspects. In Brazil, a number of studies have used the anatomy of Bromeliaceae as a tool for ecological and (or) physiological analyses (Bittencourt 2000; Segecin and Scatena 2004a, 2004b; Scatena and Segecin 2005; Proença and Sajo 2007), resolution of taxonomic problems (Sajo et al. 1998; Aoyama and Sajo 2003; Proença and Sajo 2004; Sousa et al. 2005), and structural characterization of vegetative organs (Braga 1977; Pita 1997). Only a few of the cited studies were on the subfamily Bromelioideae, using anatomy mainly as a tool for resolution of the group's taxonomy (Sajo et al. 1998; Aoyama and Sajo 2003; Proença and Sajo 2004; Sousa et al. 2005).

Dickison (2000) pointed out the importance of ecological anatomy to understand species' adaptive strategies in different environments. A number of studies have been carried out on the family Bromeliaceae with this purpose (Bittencourt 2000; Scatena and Segecin 2005; Proença and Sajo 2007) or to analyze the influence of the environment or habit on the species (Bonnet and Queiroz 2006; Dias-Pereira 2009).

For the present study, we selected species of the subfamily Bromelioideae typical of the Atlantic Forest that showed relative abundance in the sampling sites. In addition, species of epiphytic or terrestrial habits belonging to more or less related taxa were included. The objective was to characterize the anatomy of two terrestrial and two epiphytic species of the subfamily Bromelioideae occurring in the Atlantic Forest. This approach will improve knowledge of the species' adaptive strategies, describing the inherent characteristics of the group and indicating possible adaptations to the environment and to terrestrial and epiphytic habits.

\section{Materials and methods}

Plant specimens were collected from two areas of the Atlantic Forest: Serra do Brigadeiro State Park (PESB) and a forest fragment in Bom Sucesso Farm, Viçosa.

PESB is located in the Mantiqueira mountain range, Zona da Mata region, Minas Gerais, Brazil, between $42^{\circ} 20^{\prime} \mathrm{S}$ and $42^{\circ} 40^{\prime} \mathrm{S}$ and $20^{\circ} 20^{\prime} \mathrm{W}$ and $21^{\circ} 00^{\prime} \mathrm{W}$ (Engevix 1995). It spans an area of 14984 ha, with altitudes ranging from 1000 to $1995 \mathrm{~m}$ above sea level (asl). The vegetation is classified as Lower Montane Semideciduous Forest (Veloso et al. 1991).

The studied forest fragment is located within Bom Sucesso farm $\left(20^{\circ} 45^{\prime} \mathrm{S}, 42^{\circ} 55^{\prime} \mathrm{W}\right)$ in Viçosa, Minas Gerais, Brazil. It encompasses 35 ha with altitude ranging from 650 to $800 \mathrm{~m}$ asl (Campos 2002). The vegetation is classified as Semideciduous Montana Forest (Veloso et al. 1991).

According to Köeppen (1948), the climate in both areas is mesothermal subtropical highland (CWB), with an average annual rainfall of $1300 \mathrm{~mm}$, average relative humidity of $80 \%$, and an average annual temperature of $18-19{ }^{\circ} \mathrm{C}$ (Engevix 1995).

Microenvironmental data were taken near three individuals of each species, between 0900 and 1100 hours, using a Kestrel 4300 Weather Meter (Nielsen-Kellerman, Boothwyn, Pennsylvania) to measure wind speed $\left(\mathrm{m} \cdot \mathrm{s}^{-1}\right)$, temperature $\left({ }^{\circ} \mathrm{C}\right)$, relative humidity $(\%)$, and altitude (m asl). Light intensity $\left(\mu \mathrm{mol} \cdot \mathrm{m}^{-2} \cdot \mathrm{s}^{-1}\right)$ was measured with a LI-185A Photometer (LI-COR Biosciences, Inc., Lincoln, Nebraska). Means of collection sites were examined by analysis of variance and compared by the Tukey's test at 5\% of probability using the software SAEG 9.1 (2007).

Flowering specimens were collected and voucher specimens were deposited in the herbarium of the Federal University of Viçosa (VIC), Viçosa, Brazil, with subsequent confirmation of taxonomic identity. Table 1 lists species, collection sites, habit, and accession numbers at the VIC Herbarium.

Anatomical studies were performed on mature leaves that were collected from the middle part of the rosette, and sample sections were cut from the midsection of the leaf blades. 
Table 1. Species, collection sites, habit, and accession Nos. at the herbarium of the Federal University of Viçosa (VIC).

\begin{tabular}{|c|c|c|c|}
\hline Species & Collection sites & Habit & $\begin{array}{l}\text { VIC Herbarium } \\
\text { accession Nos. }\end{array}$ \\
\hline Billbergia euphemiae E. Morren & Bom Sucesso farm & Epiphytic (3 m) & 31.801 \\
\hline Bromelia antiacantha Bertol. & Bom Sucesso farm & Terrestrial & 21.643 \\
\hline Quesnelia strobilispica Wawra & $\operatorname{PESB}^{a}$ (Trilha do Moinho and Pico do Grama) & Terrestrial & $31.802,31.803$ \\
\hline Wittrockia gigantea (Baker) Leme & $\operatorname{PESB}^{a}$ (Trilha do Moinho) & Epiphytic (1.5 m) & 31.808 \\
\hline
\end{tabular}

${ }^{a}$ PESB, Serra do Brigadeiro State Park.

For all analysis, at least three leaves or leaf samples were used in this study. Also, three individuals of each species $(n=$ 3 ) were collected. The samples were fixed in FAA 50 (formalin - acetic acid - 50\% ethyl alcohol, 5:5:90 by volume) for $48 \mathrm{~h}$ (Johansen 1940) and then transferred to $70 \%$ ethyl alcohol.

For analysis of the leaf surface with scanning electron microscopy, samples of the midleaf region were dehydrated in an ethanol series and critical point dried in a Bal-Tec 030 critical point dryer (Bal-Tec, Balzers, Liechtenstein) using liquid $\mathrm{CO}_{2}$. Samples were mounted on stubs using doublesided adhesive tape and coated with gold using a FDU010 sputter coater (Bal-Tec). Examinations and photography were carried out using a Leo 1430VP scanning electron microscope (Zeiss, Cambridge, UK) at the Microscopy and Microanalysis Center, Federal University of Viçosa.

Transverse sections were prepared using a table microtome (LPC model, Rolemberg and Bhering Trade and Import LTDA, Belo Horizonte, Brazil), clarified in sodium hydroxide (20\%), and stained with astra blue and safranin (Kraus and Arduin 1997) that stains cellulosic and lignified walls, respectively, for anatomical description. The slides were mounted in glycerin gelatin.

Analysis of the surface view of the epidermis was performed using leaf samples that were cleared with a $10 \%$ sodium hydroxide solution and then were incubated in $20 \%$ sodium hypochlorite until completely cleared (Johansen 1940). The material was stained with safranin and astra blue (Kraus and Arduin 1997), and slides were mounted in glycerin gelatin.

Histochemical tests were carried out with microtome transverse sections stained with Sudan IV and (or) Sudan black B for lipid detection (Pearse 1980), phloroglucinol for lignin detection (Johansen 1940), ruthenium red for pectin detection (Johansen 1940), and lugol for starch detection (Jensen 1962). The slides were mounted in $50 \%$ glycerin.

Photographic documentation was performed using light microscopy (model AX-70 TRF, Olympus Optical, Tokyo, Japan) equipped with U-photo system, at the Laboratory of Plant Anatomy, Federal University of Viçosa.

\section{Results}

Two of the four species studied, Billbergia euphemiae and Wittrockia gigantea, are epiphytic, whereas the other two species, Bromelia antiacantha and Quesnelia strobilispica, are terrestrial. One terrestrial and one epiphytic species were sampled from each collection site (Table 1). Bromelia antiacantha is the only species in which the rosette does not form water reservoir tanks.
Table 2 shows microenvironmental data obtained during the collections. Among the assessed parameters, relative humidity (RH), altitude, and light intensity varied between the two collection sites, with the highest averages found in PESB. Although the collected species have different habits, no differences were found among the parameters evaluated in each site separately (Table 2).

The four species have peltate scales (trichomes) on both leaf surfaces, covering whole surfaces in $B$. euphemiae (Fig. 1), scattered over surfaces in W. gigantea (Fig. 8), or arranged in longitudinal rows in Bromelia antiacantha and Q. strobilispica (Figs. 3 and 5). In Bromelia antiacantha (Figs. 3 and 4), scales on the abaxial surface occur in longitudinal grooves. Disc cells do not differ from wing cells, and in B. euphemiae (Fig. 2) and Bromelia antiacantha (Fig. 4) they are round shaped, whereas in Q. strobilispica (Figs. 5 and 6) they are slightly elongated and in W. gigantea they are still more elongated (Fig. 9). The epidermal cells are rectangular, with sinuous anticlinal walls (Fig. 10).

Stomata are located in longitudinal rows on the abaxial epidermis of the leaf (Figs. 3-8) in all species. In Bromelia antiacantha, they are arranged in grooves (Fig. 3) and are wholly or partly covered by the wings of the scales (Fig. 6). In W. gigantea, stomata are on the same level as the other epidermal cells (Fig. 19), whereas in the other species they occur in depressions in the epidermis (Fig. 17).

The epidermis is uniseriate in all species, consisting of tabular cells with inner periclinal and anticlinal walls that are very thick on both surfaces. The cell lumen is greatly reduced (Figs. 11-21), with cells containing silica bodies (Fig. 11) also viewed in scanning electron microscopy (Fig. 10). The epidermal cells on both surfaces of the four species have cellulosic or partially lignified walls (Figs. 12-15, 20, and 21) and a thin cuticle covering the epidermis (Figs. 22 and 23).

The guard cells develop cutinized outer stomatal ledges (Fig. 23) and thick inner and outer cell walls, which makes the lumen very small (Figs. 17 and 19). The subsidiary cells are usually not visible in frontal view, as they project below the guard cells (Fig. 17.) In Q. strobilispica (Fig. 17) and $W$. gigantea (Fig. 19), the substomatal chamber is reduced because the sclerified hypodermis cells protrude into its cavity.

In all species, the hypodermis consists of sclerified tissue and water storage tissue (hydrenchyma). The sclerified hypodermis occurs on both leaf surfaces (consisting of one to three layers of cellulosic or partially lignified cell walls; Figs. 12-15, 20, and 21) and can be discontinuous in B. euphemiae (Fig. 13).

The aquiferous hypodermis extends toward the adaxial side, under the sclerified hypodermis, formed by three to 
Table 2. Microenvironmental data of the four species analyzed.

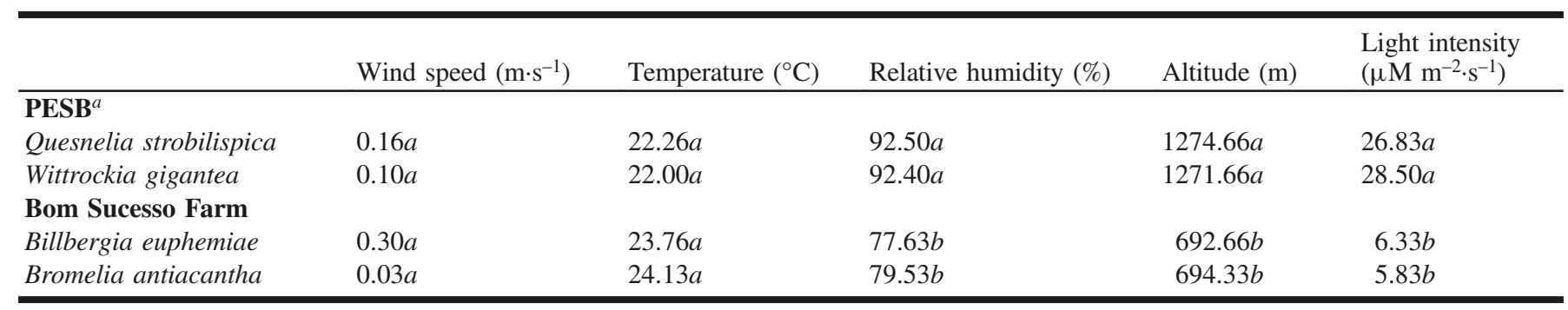

Note: Averages followed by the same letter do not differ by the Tukey's test at $5 \%$ of probability.

${ }^{a}$ PESB, Serra do Brigadeiro State Park.

nine layers of large nonchlorophyllous cells (Figs. 25-28). In Bromelia antiacantha (Fig. 27) and W. gigantea (Fig. 28), all the water storage tissue (aquiferous hypodermis) consists of isodiametric cells. In B. euphemiae (Fig. 25) and Q. strobilispica (Fig. 26), the first layers have round shaped cells and the other layers have cells elongated anticlinally and folding in an accordion-pleated or concertina pattern, as a result of reversible cell shrinkage (Fig. 26).

The chlorenchyma is usually subjacent to the hypodermis and formed by isodiametric cells (Figs. 25-28). Bromelia antiacantha (Fig. 27) and W. gigantea (Fig. 28) have chlorenchyma protruding into some regions of the adaxial surface, interrupting the aquiferous hypodermis. Air channels formed by stellate cells appear in all species, longitudinally arranged between vascular bundles and contiguous to substomatal chambers (Figs. 25-28). Billbergia euphemiae, in particular, showed starch grains evenly distributed throughout the chlorenchyma (Fig. 24). Groups of sclerenchyma fibers, which were not associated with vascular bundles, appeared in the region of the abaxial chlorenchyma in $B$. euphemiae (Fig. 25) and Q. strobilispica (Fig. 26), and both species have cellulosic cell walls (Fig. 13).

All species have collateral vascular bundles arranged in a single series throughout the leaf blade that are interspersed with air channels, alternating between larger and smaller diameters (Figs. 25-28). Vascular bundles of B. euphemiae and $Q$. strobilispica occur in the lower half of the leaf blade, whereas in the other species they are embedded in the middle of the mesophyll, and in W. gigantea the sclerenchyma cap extends to the adaxial side (Fig. 28). The large-diameter bundles are surrounded by fiber sheaths with little or no lignification in B. euphemiae (Figs. 29-31) and Bromelia antiacantha (Figs. 32-34) as indicated by phloroglucinol and ruthenium red staining, or by strongly lignified fibers as in Q. strobilispica (Figs. 35-37) and W. gigantea (Figs. 3840). Vascular bundles may also present nonlignified sclerenchyma caps adjacent to the xylem and phloem, especially in bundles of smaller diameters, as in B. euphemiae (Figs. 25 and 29-31) and Q. strobilispica (Figs. 26 and 35-37). Wittrockia gigantea has more developed sclerenchyma caps, formed by partially lignified fibers (Figs. 28 and 38-40). In Q. strobilispica (Figs. 35-37) and W. gigantea (Figs. 3840 ), cells with lignified walls occur between the vascular tissues in the large bundles.

\section{Discussion}

The species were collected from environments in the forest interior, which, although relatively moist and shady, may be subject to wide microenvironmental variations because of cloud formation, sunflecks formed by light passing through the canopy, and the height of epiphytes on host tree species, among other factors (Bonnet and Queiroz 2006; Andrade et al. 2009). Nevertheless, the climatic data in this study showed no significant differences between terrestrial and epiphytic species in the same site. The variations between the two sampling sites suggest that the environment has greater influence on the species than plant habit.

Gilmartin and Brown (1987) considered the presence of peltate scales as a synapomorphy for bromeliads, and many functions, including water and nutrient absorption, reduction of transpiration, protection against solar radiation, predators, and pathogens, have been attributed to these structures (Benzing 2000). The function of absorption is extremely important, especially for epiphytic species such as $B$. euphemiae and $W$. gigantea, because their habit restricts the uptake of water from the soil.

In all four species, peltate scales appear in different shapes, and the shield can be formed by round to elongated cells. Such characteristics, together with the similarity between disc and wing cells, confirm Strehl's (1983) observations that the subfamily Bromelioideae shows the largest variations in scale shape, pointing out possible differences within a species or even in a single leaf. The variability of this character indicates that caution should be exercised when using it in making taxonomic considerations at species and genus level within the subfamily Bromelioideae. Strehl (1983) also associated the arrangement of scales in rows, especially on the abaxial surface, with terrestrial and mesoepiphytic species, considering it as a plesiomorphic character for Bromeliaceae.

The presence of silica bodies inside the epidermal cells observed here has been reported for other species of Bromeliaceae (Tomlinson 1969; Sajo et al. 1998; Aoyama and Sajo 2003; Proença and Sajo 2004, 2007; Sousa et al. 2005). Other families of Poales also have silica bodies (APG II 2003), which suggests that this is a plesiomorphic character for the order. These structures are associated with light reflection, reducing heat and the consequent water loss through internal tissues, as well as protecting against insect and pathogen attacks (Yoshida et al. 1962).

The arrangement of stomata in grooves on the abaxial surface and their covering by scales can minimize water loss by transpiration, which is an important adaptation to conditions of low water availability (Benzing 2000). Proença and Sajo (2007) considered the position of stomatal guard cells as a fixed character within species from different cerrado physiognomies (from field environments to forests environments). 
Figs. 1-10. Leaf surfaces of Bromeliaceae species. Figs. 1-3 and 5-10. Scanning electron microscopy. Fig. 4. Clearing. Figs. 1, 3, 5, and 8. Scale arrangement on the abaxial surface. Figs. 2, 4, and 9. Detail of scales. Fig. 6. Detail of stomata partially covered by scales. Fig. 7. Detail of stomata. Fig. 10. Epidermal cells containing silica bodies (arrows). SB, silica body; Sc, scale; St, stomata.
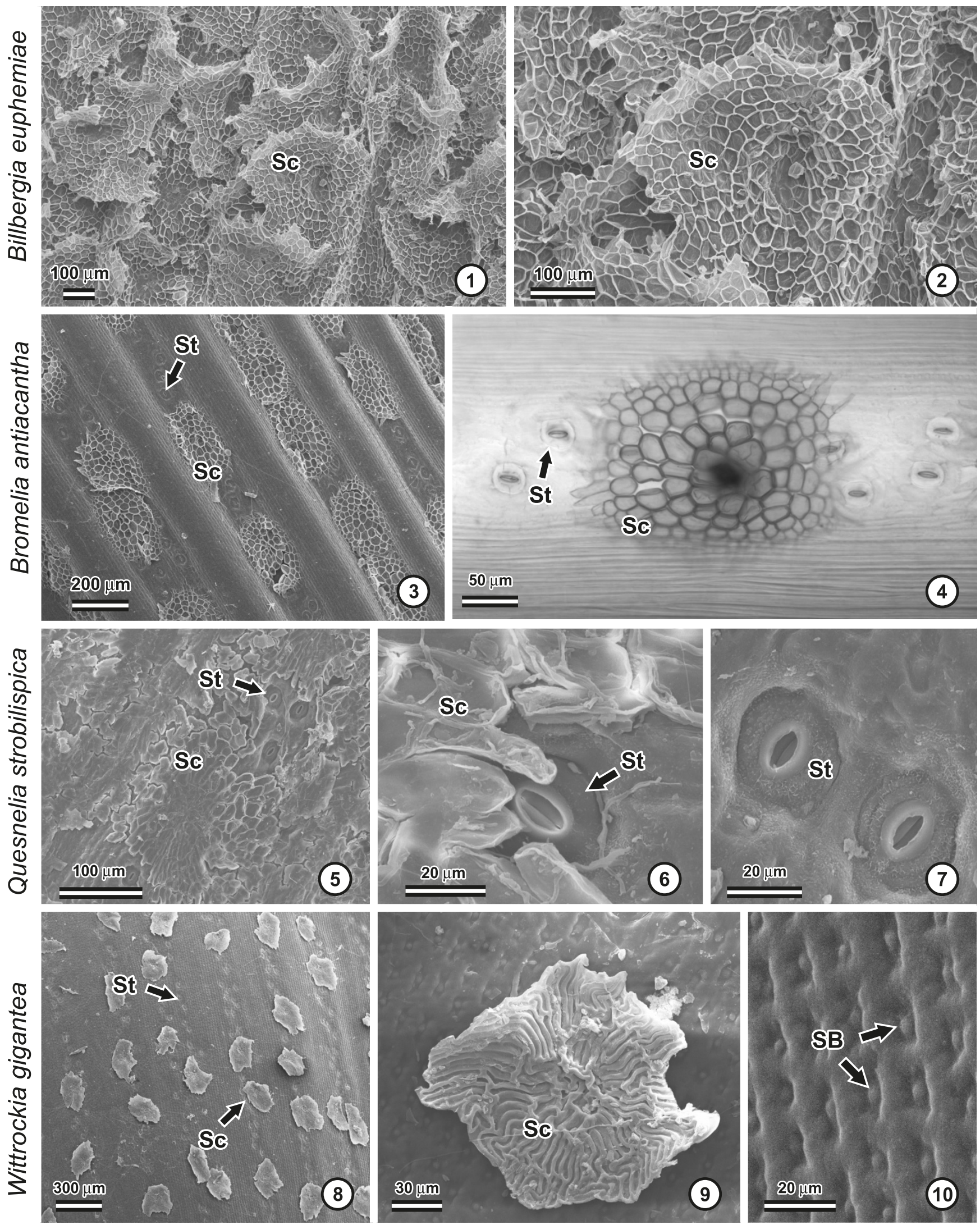
Figs. 11-21. Leaf structure of Bromeliaceae species (transverse sections). Figs. 11, 12, 14, 16, and 18. Adaxial surface. Figs. 13, 15, 17, and 19-21. Abaxial surface. Figs. 11 and 16-19. Safranin and astra blue staining. Figs. 12-15 and 20. Reaction to ruthenium red. Fig. 21. Reaction to phloroglucinol. Fig. 11. Epidermal cell containing silica body. Fig. 16. Reduced lumen of epidermal cells (arrowhead). Fig. 17. Stomata below the level of epidermal cells with subsidiary cells protruding below guard cells (arrows). Fig. 19. Stomata on the same level of epidermal cells and guard cells with reduced lumen. E, epidermis; Fi, fiber; Lu, cell lumen; SB, silica body; Sc,scale; SH, sclerified hypodermis; St, stomata; Su, substomatal chamber. Bars, $30 \mu \mathrm{m}$.
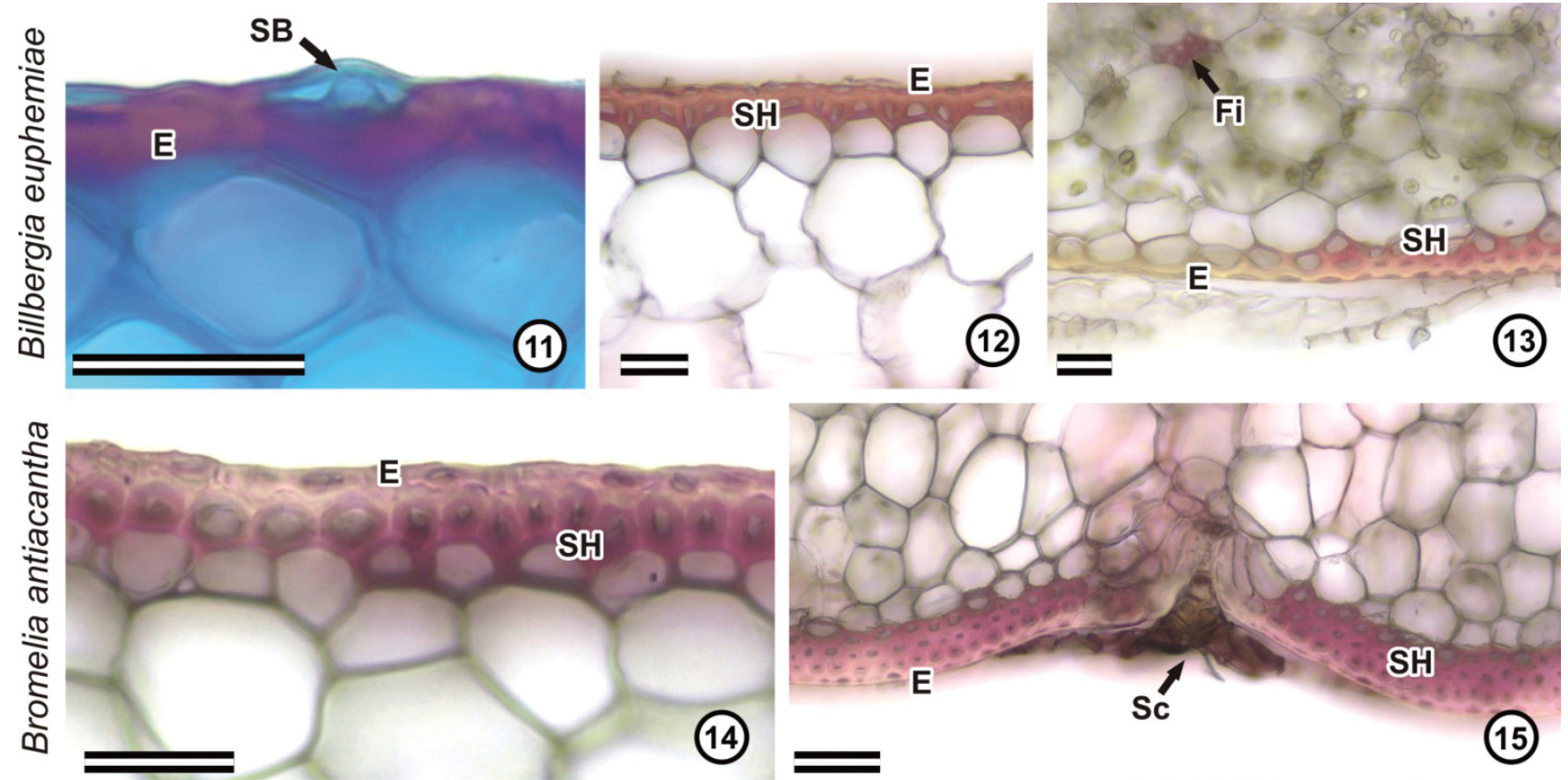

(14)

(15)
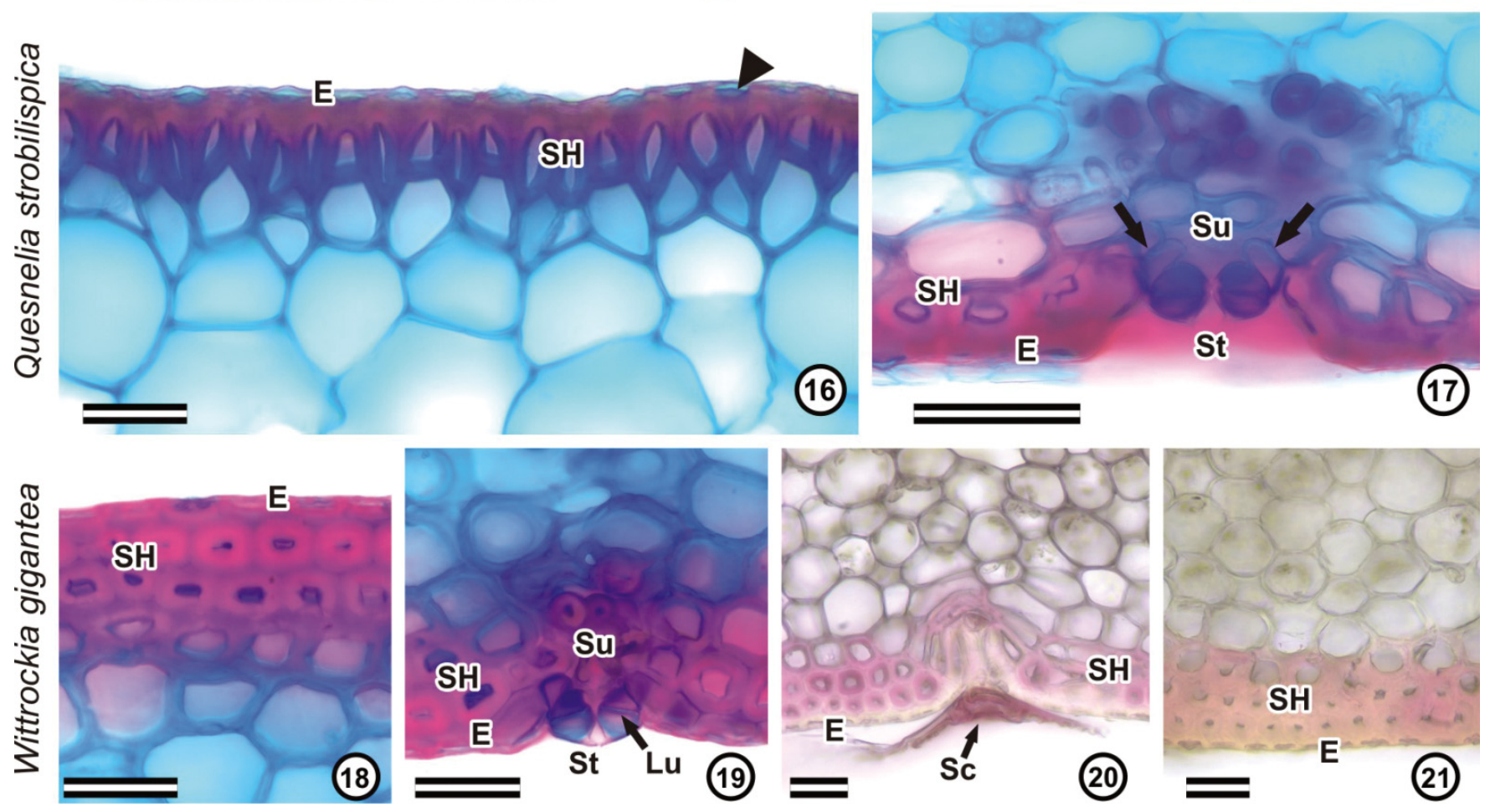
Figs. 22-28. Leaf structure of Bromeliaceae species (transverse sections). Figs. 22, 23, and 28. Wittrockia gigantea. Figs. 24 and 25. Billbergia euphemiae. Fig. 26. Quesnelia strobilispica. Fig. 27. Bromelia antiacantha. Figs. 22 and 23. Reaction of cuticle to Sudan red. Fig. 24. Reaction of starch grains to lugol. Figs. 25-28. Overview. Arrowheads indicate sclerenchyma caps in the vascular bundle and the asterisk indicates chlorenchyma extending to the adaxial surface. AH, aquiferous hypodermis; $\mathrm{Cl}$, chlorenchyma; $\mathrm{Cu}$, cuticle; E, epidermis; Fi, fiber; GC, guard cell; Sc, scale; SH, sclerified hypodermis; SP, stellate parenchyma; St, stomata; VB, vascular bundle. Bars, $30 \mu \mathrm{m}$ in Figs. $22-24$; $200 \mu \mathrm{m}$ in Figs. 25-28.
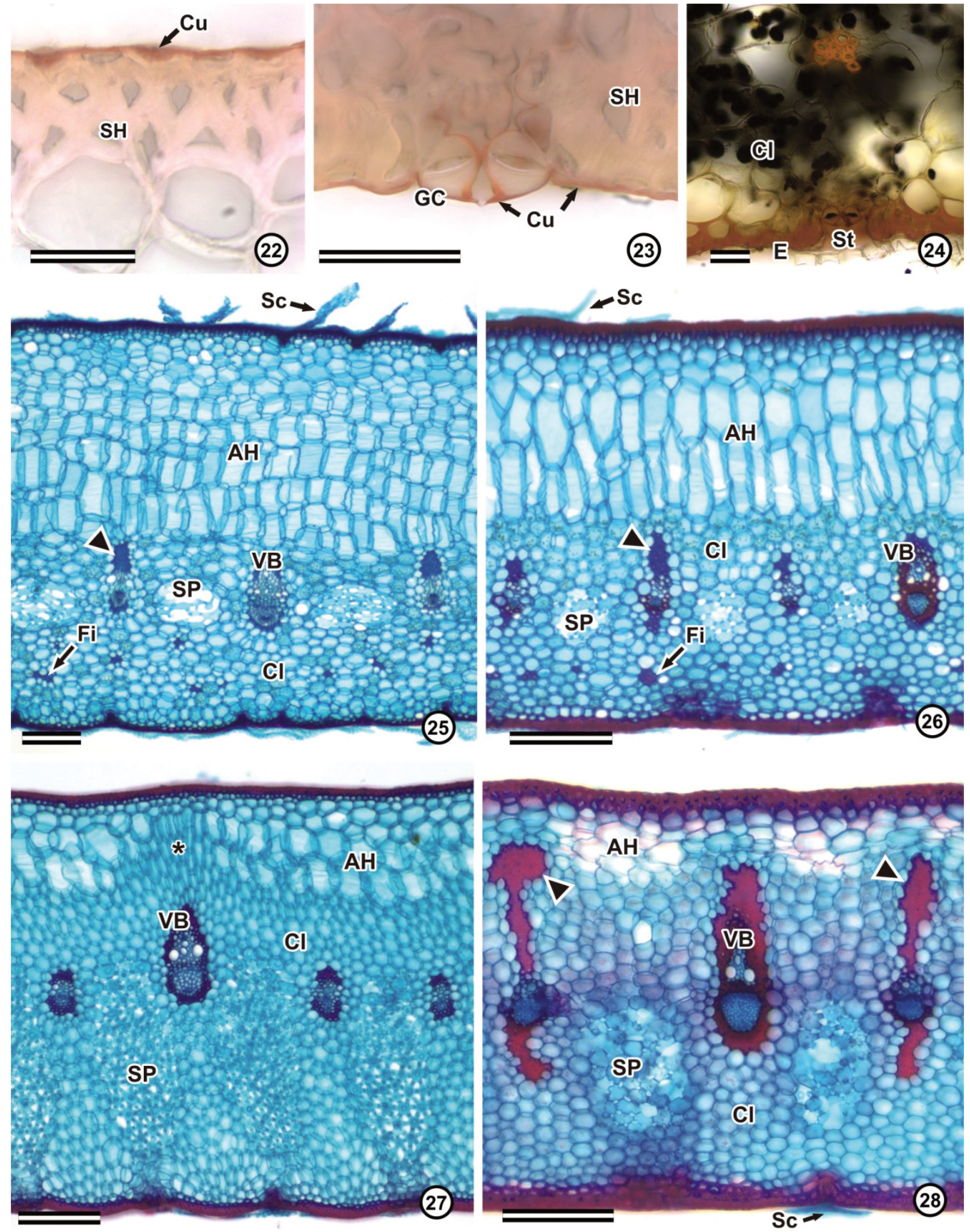
Figs. 29-40. Leaf vascular bundles in Bromeliaceae species (transverse sections). Figs. 29, 32, 35, and 38. Contrast staining with Safranin and astra blue. Figs. 30, 33, 36, and 39. Reaction to ruthenium red. Figs. 31, 34, 37, and 40. Reaction to phloroglucinol. Arrowheads indicate nonlignified sclerenchyma caps and the arrow indicates lignified cells between the vascular tissues. P, phloem; X, xylem. Bars, $50 \mu \mathrm{m}$.
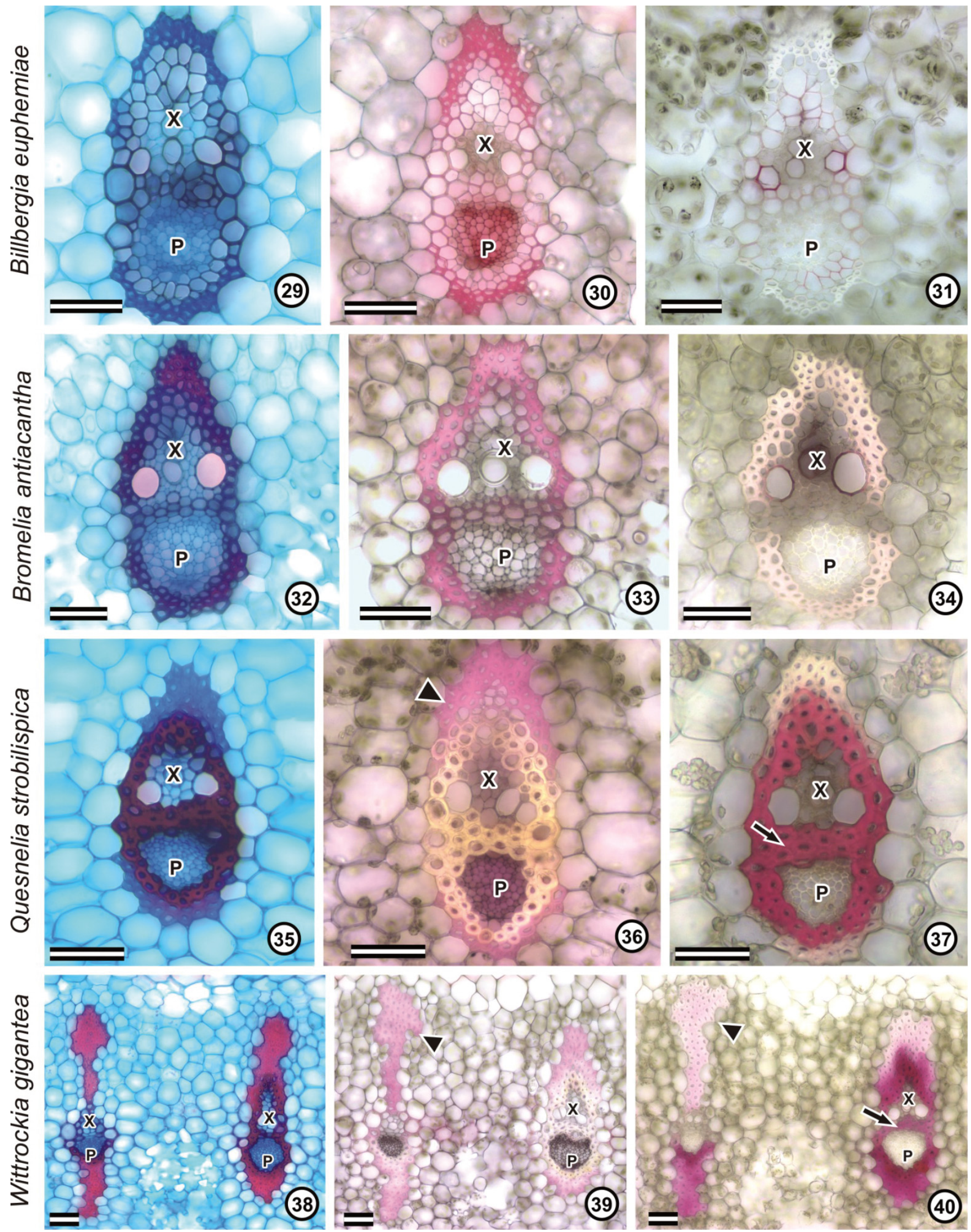

Published by NRC Research Press 
Although some studies have classified stomata in Bromeliaceae as tetracytic (Proença and Sajo 2004; Sousa et al. 2005), the arrangement of subsidiary cells, which protrude below the guard cells and are not visible in frontal view, prevented stomatal classification in the studied species.

Several authors have reported the presence of epidermal cells with sinuous anticlinal walls in frontal view, which is a remarkable characteristic in Bromeliaceae (Krauss 1949; Tomlinson 1969; Proença and Sajo 2004, 2007). Krauss (1949) suggested that the sinuosity of the cell walls provides greater mechanical resistance to the epidermal tissue, increases the surface contact between the cells, and prevents cell collapse during expansion and contraction movements in response to changes in leaf turgor.

The thickening of epidermal and hypodermal cell walls observed in the species studied is another remarkable characteristic in Bromeliaceae, as stated by Tomlinson (1969). This epidermis-hypodermis complex is a mechanical reinforcement of leaf structure. It protects against strong winds and reduces water evaporation from internal tissues, preventing mesophyll collapse in unfavorable abiotic conditions (Fahn and Cutler 1992). Tests to determine the chemical nature of the cell walls in the epidermis-hypodermis complex were not conclusive, because the positive reaction to ruthenium red and phloroglucinol were in some cases inconsistent. Histochemical tests on epidermal tissues of $Q$. strobilispica and $W$. gigantea showed no positive reaction to any of the tests, and in Bromelia antiacantha there was a weak reaction to ruthenium red. This result indicates a need for further, more specific testing to determine the chemical nature of these cell walls.

The aquiferous hypodermis is also a prominent characteristic in Bromeliaceae (Tomlinson 1969; Sajo et al. 1998). The fact that this tissue is poorly developed in Bromelia antiacantha and $W$. gigantea, and conversely, well developed in B. euphemiae and $Q$. strobilispica, may reflect different microclimatic conditions to which the species were subjected. The hydrenchyma stores the water absorbed by the scales, protects the chlorenchyma from intense light, enhances photosynthesis, and reduces water loss through air canals (Brighigna et al. 1984).

Although the mesophyll is, as a rule, a homogeneous tissue, Proença and Sajo $(2004,2007)$ identified layers of palisade cells in the chlorenchyma of some species of the genera Aechmea, Billbergia, and Bromelia. The occurrence and variations found in the stellate parenchyma of the four species were also reported by Aoyama and Sajo (2003) and Proença and Sajo (2007). This parenchyma, located between vascular bundles and connected to the substomatal chambers, is a long system of air channels that extend without interruption in the leaf, providing a connection between the inside and outside atmospheres. Tomlinson (1969) also suggested that these channels facilitate aeration in species from mesic environments, such as the species studied here.

The occurrence of extravascular fiber groups was reported for several species of Bromelioideae by Tomlinson (1969), Sajo et al. (1998), Aoyama and Sajo (2003), Proença and Sajo (2004, 2007), and Sousa et al. (2005). Proença and Sajo (2007) observed that this is a common characteristic in Bromelioideae but rare in Tillandsioideae and absent in Pitcairniodeae, indicating that this feature is associated with specific taxonomic groups, without adaptive significance in the cerrado environments studied by the authors. In our study, the occurrence of these fiber groups in the epiphytic $B$. euphemiae and the terrestrial $Q$. strobilispica indicates that this characteristic is not a significant adaptation to the habit, but rather an inherent characteristic of the species, corroborating the hypothesis by Proença and Sajo (2007).

The presence of sheaths of thick-walled cells around large bundles was reported by Proença and Sajo $(2004,2007)$ and Sousa et al. (2005). We observed that these sheaths can be lignified in $Q$. strobilispica and $W$. gigantea or nonlignified in Bromelia antiacantha and B. euphemiae. Sclerenchyma caps adjacent to xylem and phloem were also observed by other authors (Sajo et al. 1998; Aoyama and Sajo 2003; Proença and Sajo 2004, 2007; Sousa et al. 2005) and may be related to leaf mechanical resistance. In $W$. gigantea, the sclerenchyma caps extend toward the adaxial side. Lignified cells in tissues between the large bundles of $Q$. strobilispica and W. gigantea were also observed by Flores (1975) and Pita (1997) in other species of the Bromeliaceae.

Among the studied species, the epiphytic B. euphemiae and the terrestrial $Q$. strobilispica have very similar overall structure, such as a well-developed parenchyma and extravascular fiber groups. In turn, the terrestrial Bromelia antiacantha and the epiphytic W. gigantea also show similarities in their structures, for example, absence of extravascular fiber groups and a less-developed water storage tissue. As previously discussed, there was no significant difference in microenvironmental data between terrestrial and epiphytic species from the same site. Further studies addressing other characteristics of the collection environments, such as soil conditions in the case of terrestrial species, and differences in plant height on the host tree in the case of epiphytes, will be of great help for these interpretations. The xeromorphic characteristics observed in this study should not be considered only as adaptive strategies related to a particular environment, but may represent ancestral adaptations selected during the diversification of the group (Benzing 2000; Proença and Sajo 2007). In this case, phylogenetic studies are vital to understanding the relationships among the species and similarities observed in the morpho-anatomical structure.

Recent studies have confirmed the closeness of the genus Quesnelia, especially the subgenus Billbergiopsis that comprises Q. strobilispica, to the genus Billbergia (Vieira 2006; Almeida et al. 2009). This may explain the anatomical similarity between $B$. euphemiae and $Q$. strobilispica, despite being from different sites and having different habits.

Schulte et al. (2009) and Horres et al. (2007) reported that the genera Billbergia and Quesnelia appear close to the genus Wittrockia within the core group of subfamily Bromelioideae, indicating that they are more derived genera. The genus Bromelia, however, had its basal position within the subfamily Bromelioideae confirmed by the same authors, who pointed out the presence of basal characteristics such as terrestrial habit, absence of reservoir tank, and presence of nonabsorbent scales.

Givnish et al. (2007) observed that the epiphytic habit, the most derived character for the Bromeliaceae, would have emerged independently at least three times in the family, emphasizing that the presence of similar characteristics in different groups is the result of adaptive convergence. 
The similarities in anatomical structure of B. euphemiae and $Q$. strobilispica may be due to the closeness of these species, whereas the similarities observed between phylogenetically more distant species, such as $W$. gigantea and Bromelia antiacantha, can be explained by the adaptive convergence in the family, which are genetically fixed characteristics, receiving little environmental influence.

\section{Acknowledgements}

We thank the Núcleo de Microscopia e Microanálise at the Universidade Federal de Viçosa, Gilmar Valente for help with the collections, Rafaela Campostrini Forzza and Thiago dos Santos Coser for species identification, Evelyn Jardim de Oliveira for translation and suggestions on the manuscript, and the Fundação de Amparo à Pesquisa do Estado de Minas Gerais for financial support of the project.

\section{References}

Almeida, V.R., Costa, A.F., Mantovani, A., Gonçalves-Esteves, A., Arruda, R.C.O., and Forzza, R.C. 2009. Morphological phylogenetics of Quesnelia (Bromeliaceae, Bromelioideae). Syst. Bot. 34 (4): 660-672. doi:10.1600/036364409790139619.

Andrade, J.L., Cervera, J.C., and Graham, E.A. 2009. Microenvironments, water relations, and productivity of CAM plants. In Perspectives in biophysical plant ecophysiology. Edited by E. De La Barrera and W.K. Smith. Universidad Nacional Autónoma de México, México City, México. pp. 95-120.

Aoyama, E.M., and Sajo, M.G. 2003. Estrutura foliar de Aechmea Ruiz \& Pav. subgênero Lamprococcus (Beer) Baker e espécies relacionadas. Rev. Bras. Bot. 26(4): 461-473. [In Portuguese.] doi:10.1590/S0100-84042003000400005.

APG II. 2003. An update of the Angiosperm Phylogeny Group classification for the orders and families of flowering plants: APG II. Bot. J. Linn. Soc. 141(4): 399-436. doi:10.1046/j.1095-8339. 2003.t01-1-00158.x.

Benzing, D.H. 2000. Bromeliaceae: profile of an adaptive radiation. Cambridge University Press, Cambridge, UK.

Bittencourt, A.H.C. 2000. Anatomia foliar de espécies do gênero Vriesea Lindl (Bromeliaceae) no Parque Estadual da Serra do Brigadeiro (MG). M.Sc. thesis, Universidade Federal de Viçosa, Minas Gerais, Brazil. [In Portuguese.]

Bonnet, A., and Queiroz, M.H. 2006. Estratificação vertical de bromélias epifíticas em diferentes estádios sucessionais da Floresta Ombrófila Densa, Ilha de Santa Catarina, Santa Catarina, Brasil. Rev. Bras. Bot. 29(2): 217-228. [In Portuguese.]

Braga, M.M.N. 1977. Anatomia foliar de Bromeliaceae da Campina. Acta Amaz. 7(3), Suplemento. [In Portuguese.]

Brighigna, L., Fiordi, A.C., and Palandri, M.R. 1984. Structural characteristics of mesophyll in some Tillandsia species. Phytomorphology, 34: 191-200.

Campos, E.P. 2002. Florística e Estrutura Horizontal da Vegetação Arbórea de uma Ravina em um Fragmento Florestal no Município de Viçosa (MG). M.Sc. thesis, Universidade Federal de Viçosa, Minas Gerais, Brazil. [In Portuguese.]

Dias-Pereira, J. 2009. Aspectos ecológicos e anatômicos de epífitas vasculares da Trilha do Muriqui, Parque Estadual da Serra do Brigadeiro, Araponga, Minas Gerais. Ph.D. thesis, Universidade Federal de Viçosa, Minas Gerais, Brazil. [In Portuguese.]

Dickison, W.C. 2000. Integrative plant anatomy. Academic Press, San Diego, Calif.

Engevix. 1995. Caracterização do Meio Físico da Área Autorizada para a criação do Parque Estadual da Serra do Brigadeiro -
Relatório técnico final dos estudos-8296-RE-H4-003/94 "VER. 1". IEF/BIRD/PRÓ-FLORESTA/ SEPLAN. [In Portuguese.]

Fahn, A., and Cutler, D.F. 1992. Xerophytes. In Encyclopedia of plant anatomy. Band XIII, Teil 3. Gebrüder Borntraeger, Berlin, Germany.

Flores, E.M. 1975. Algunos aspectos de anatomia foliar comparada de dos especies de Bromeliaceae (Aechmea mexicana Baker y Hechtia glomerata Zucc.). Rev. Biol. Trop. 23(1): 29-52. [In Portuguese.] PMID:1197816.

Gilmartin, A.J., and Brown, G.K. 1987. Bromeliales, related monocots, and resolution of relationships among Bromeliaceae subfamilies. Syst. Bot. 12(4): 493-500. doi:10.2307/2418884.

Givnish, T.J., Millam, K.C., Berry, P.E., and Sytsma, K.J. 2007. Phylogeny, adaptive radiation, and historical biogeography of Bromeliaceae inferred from ndhF sequence data. Aliso, 23: 3-26.

Horres, R., Schulte, K., Weising, K., and Zizka, G. 2007. Systematics of Bromelioideae (Bromeliaceae) - evidence from molecular and anatomical studies. Aliso, 23: 27-43.

Jacques-Felix, H. 2000. The discovery of a bromeliad in Africa: Pitcairnia feliciana. Selbyana, 21: 118-124.

Jensen, W.A. 1962. Botanical histochemistry: principles and practice. 1st ed. WH Freeman, San Francisco, Calif.

Johansen, D.A. 1940. Plant microtechnique. 1st ed. McGraw-Hill, New York.

Köeppen, W. 1948. Climatologia: con un estudio de los climas de la tierra. Fondo de Cultura Económica, México City, México. [In Spanish.]

Kraus, J.E., and Arduin, M. 1997. Manual básico de métodos em morfologia vegetal. EDUR, Rio de Janeiro, Brazil. [In Portuguese.]

Krauss, B.H. 1949. Anatomy of the vegetative organs of the pineapple, Ananas comosus (L.) Merr. II. The leaf. Bot. Gaz. 110(3): 333-404. doi:10.1086/335540.

Luther, H.E. 2008. An alphabetical list of bromeliad binomials. 11th ed. The Bromeliad Society International, Sarasota, Fla.

Martinelli, G., Vieira, C.M., Gonzalez, M., Leitman, P., Piratininga, A., Costa, A.F., and Forzza, R.C. 2008. Bromeliaceae da Mata Atlântica Brasileira: lista de espécies, distribuição e conservação. Rodriguésia, 59(1): 209-258. [In Portuguese.]

Pearse, A.G.E. 1980. Histochemistry theoretical and applied. Vol. 2. 4th ed. Churchill Livingston, Edinburgh, UK.

Pita, P.B. 1997. Estudo anatômico dos órgãos vegetativos de Dyckia Schultz f. e Encholirium Mart. ex Schultz f. (Bromeliaceae) da Serra do Cipó - MG. M.Sc. thesis, Instituto de Biociências, Universidade de São Paulo, São Paulo, Brazil. [In Portuguese.]

Proença, S.L., and Sajo, M.G. 2004. Estrutura foliar de espécies de Aechmea Ruiz \& Pav. (Bromeliaceae) do Estado de São Paulo, Brasil. Acta Bot. Bras. 18(2): 319-331. [In Portuguese.] doi:10. 1590/S0102-33062004000200011.

Proença, S.L., and Sajo, M.G. 2007. Anatomia foliar de bromélias ocorrentes em áreas de cerrado do Estado de São Paulo, Brasil. Acta Bot. Bras. 21(3): 657-673. [In Portuguese.] doi:10.1590/ S0102-33062007000300013.

Reitz, R. (Editor). 1983. Bromeliáceas e a malária — bromélia endêmica. In Flora Ilustrada Catarinense. Parte 1, fasc. Bromélia. Herbário Barbosa-Rodrigues, Itajaí, Brazil. [In Portuguese.] pp.1559.

SAEG. 2007. Sistema para Análises Estatísticas, Version 9.1. Fundação Arthur Bernardes, Universidade Federal de Viçosa, Minas Gerais, Brazil [In Portuguese].

Sajo, M.G., Machado, S.R., and Carmello-Guereiro, S.M. 1998. Aspectos estruturais de folhas de bromélias e suas implicações no agrupamento de espécies. In Canistropsis: Bromélias da Mata Atlântica. Edited by E.M.C. Leme. Salamandra, Rio de Janeiro, Brazil. [In Portuguese.] pp.101-111. 
Scatena, V.L., and Segecin, S. 2005. Anatomia foliar de Tillandsia L. (Bromeliaceae) dos Campos Gerais, Paraná, Brasil. Rev. Bras. Bot. 28(3): 635-649. [In Portuguese.] doi:10.1590/S010084042005000300019.

Schulte, K., Barfuss, M.H.J., and Zizka, G. 2009. Phylogeny of Bromelioideae (Bromeliaceae) inferred from nuclear and plastid DNA loci reveals the evolution of the tank habit within the subfamily. Mol. Phylogenet. Evol. 51(2): 327-339. doi:10.1016/j. ympev.2009.02.003. PMID:19236934.

Segecin, S., and Scatena, V.L. 2004a. Anatomia de escapos de Tillandsia L. (Bromeliaceae) dos Campos Gerais do Paraná, Brasil. Rev. Bras. Bot. 27(3): 515-525. [In Portuguese.] doi:10. 1590/S0100-84042004000300011.

Segecin, S., and Scatena, V.L. 2004b. Morfoanatomia de rizoma e raízes de Tillandsia L. (Bromeliaceae) dos Campos Gerais, PR, Brasil. Acta Bot. Bras. 18(2): 253-260. [In Portuguese.] doi:10. 1590/S0102-33062004000200005.

Smith, L.B., and Downs, R.J. 1974. Pitcairnioideae (Bromeliaceae). Flora Neotrop. Monogr. 14(1): 1-658.

Smith, L.B., and Downs, R.J. 1977. Tillandsioideae (Bromeliaceae). Flora Neotrop. Monogr. 14(2): 663-1492.

Smith, L.B., and Downs, R.J. 1979. Bromelioideae (Bromeliaceae). Flora Neotrop. Monogr. 14(3): 1493-2142.

Fundação SOS Mata Atlântica and Instituto Nacional de Pesquisas Espaciais. 2008. Atlas dos remanescentes florestais da Mata Atlântica e ecossistemas associados no período de 2000-2005. Fundação SOS Mata Atlântica \& INPE, São Paulo, Brazil. [In Portuguese.]
Sousa, G.M., Estelita, M.E.M., and Wanderley, M.G.L. 2005. Anatomia foliar de espécies brasileiras de Aechmea subg. Chevaliera (Gaudich. ex Beer) Baker, BromelioideaeBromeliaceae. Rev. Bras. Bot. 28(3): 603-613. [In Portuguese.]

Strehl, T. 1983. Forma, distribuição e flexibilidade dos tricomas foliares usados na filogenia de Bromeliáceas. Iheringia Ser. Bot. 31: 105-119. [In Portuguese.]

Tomlinson, P.B. 1969. Comelinales - Zingiberales. In Anatomy of the monocotyledons. Vol. 3. Edited by C.R. Metcalfe. Oxford University Press, London. pp. 193-294.

Veloso, H.P., Rangel-Filho, A.L.R., and Lima, J.C. 1991. Classificação da vegetação brasileira, adaptada a um sistema universal. Instituto Brasileiro de Geografia e Estatística, Rio de Janeiro, Brazil. [In Portuguese.]

Versieux, L.M., and Wendt, T. 2006. Checklist of Bromeliaceae of Minas Gerais, Brazil, with notes on taxonomy and endemism. Selbyana, 27(2): 107-146.

Versieux, L.M., and Wendt, T. 2007. Bromeliaceae diversity and conservation in Minas Gerais state, Brazil. Biodivers. Conserv. 16 (11): 2989-3009. doi:10.1007/s10531-007-9157-7.

Vieira, C.M. 2006. Quesnelia Gaudich. (Bromelioideae: Bromeliaceae) do estado Rio de Janeiro, Brasil. Pesqui. Bot. 57: 7-102. [In Portuguese.]

Yoshida, S., Ohnishi, Y., and Kitagishi, K. 1962. Histochemistry of silicon in rice plant. III. The presence of cuticle-silica double layer in the epidermal tissue. Soil Sci. Plant Nutr. 8: 1-5. 
Copyright of Botany is the property of Canadian Science Publishing and its content may not be copied or emailed to multiple sites or posted to a listserv without the copyright holder's express written permission. However, users may print, download, or email articles for individual use. 